\title{
Magnetic Studies of Kagoro and Environs, North Central Nigeria
}

\author{
Samaila Crah Alkali ${ }^{1}$, Muhammad Hassan ${ }^{2}$ \\ ${ }^{\prime \prime}$ Department of Geology, University of Maiduguri, Nigeria) \\ ${ }^{21}$ Department of Physics, University of Maiduguri, Nigeria)
}

\begin{abstract}
Magnetic data were compiled from four aeromagnetic maps. A submap for the study area was produced from the four magnetic sheets in an ILWIS environment. Magnetic intensity values vary between 32,600 and 33,160 nT. The lowest magnetic contour values closure is centred over the Kagoro granite rocks at the central part. This closure is structurally aligned along the $N E-S W$ direction. Regional field values vary between7789.1 and $7896.6 \mathrm{mGal}$. The residual contour values range from -180 to $+160 \mathrm{nT}$. The main closure of the residual map is located on the central part of the area. A slipper-shaded closure centred over the Kagoro Granite is oriented along the NNE - SSW direction. Some of the closures in the study area are aligned along the $N E-S W$ and $E-W$ directions. Patterns of the closures of the magnetic maps are in conformity with those of the Nigeria basement and younger granite rocks. Isolations and magnitudes of the closures suggest that the various rock bodies occur separately and at different levels. The regional fields along nine profiles were obtained by third degree polynomial fitting using OriginLab7 software so as to obtain the residuals used for the models. The residual anomalies were accounted for by Mag2dc (2.5D) algorithms. The four profiles that traversed the Kagoro younger granite complex were estimated at maximum thicknesses of 14.1, 15.2, 9.5 and $10.4 \mathrm{~km}$. These suggest that the Kagoro younger granite complex was emplaced at depths between 9.5 and 15.2 $\mathrm{km}$. The volcanic rocks and their associates were formed from depths between 4.7 and $13.0 \mathrm{~km}$.
\end{abstract}

Keywords: Closure, emplacement, granite, Kagoro, magnetic, structure

\section{Introduction}

The topography of Nigeria is influenced by planar and linear structures resulting from both ductile and brittle deformational events [1]. The structures generally have $\mathrm{N}-\mathrm{S}, \mathrm{NE}-\mathrm{SW}, \mathrm{NW}-\mathrm{SE}$ and sometimes $\mathrm{E}-\mathrm{W}$ trends [2], [3], [4] and [5]. Regional strikes of foliations in basement rocks, lithologic boundaries, fold axes and axial planes maintain the $\mathrm{N}-\mathrm{S}$ Pan-African trend. Throughout the country, there are numerous fractures and faults forming river valleys.

Local lineaments indicating jointing and fracturing in rocks are discernable in aerial photographs. The lineaments are mostly fracture lines defined by joints that formed as a result of tensional stresses. These form a network criss crossing each other, which often decrease in width and size with increase in depth, as they are commonly sealed up at depth by the weight of the overlying rocks and/or siliceous melt at their flow stages.

Sensing for aeromagnetic data is a quick and efficient way to scan broad areas, to examine regions having rugged topography or hostile climate that cannot easily be explored on foot or with surface-based vehicles, and to view areas which ground access is limited for political reasons.

Kagoro and its environs in North Central Nigeria shown in Fig. 1 is bounded by latitudes $9^{\circ} 08^{\prime} 41.2^{\prime \prime}-$ $9^{\circ} 56^{\prime} 22.5^{\prime \prime} \mathrm{N}$ and between longitudes $8^{\circ} 06^{\prime} 30.0^{\prime \prime}-8^{\circ} 42^{\prime} 51.2^{\prime \prime} \mathrm{E}$. The area comprises parts of the Federal Survey of Nigeria sheets 167 (Kafanchan SE), 168 (Naraguta SW), 188 (Jema'a NE) and 189 (Kurra NW) in Kaduna and Plateau States, Nigeria. It covers an area of about $5827 \mathrm{~km}^{2}$.

The study is aimed at determining the structural extent of Kagoro rocks and other structural features around it and to delineate any fault that may or may not had cut across the Kagoro granite complex.

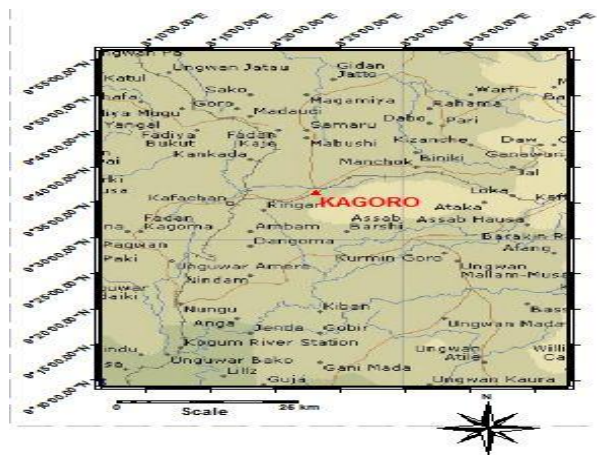

Fig. 1 Location Map of the Study Area (Source [6]) 


\section{Geology}

The Younger Granite province comprises of Precambrian to Lower Paleozoic Basement Complex rocks into which the Younger Granites suites are emplaced [7]. Basement rocks cover about three quarters of the Younger Granites province and consist of ancient sediments which are made up of granulitic gneiss, dioritic rocks, migmatites, granite-gneiss, older granites and granodiorites [7], [8] and [9]. Cone sheets and ring dykes are widely distributed in the province. The ring dykes show outward dips both on the inner and outer contacts but some have steep or vertical contacts [10], [11] and [7].

The Younger Granite complexes trend in an $\mathrm{N}-\mathrm{S}$ belt with the ages of the complexes decreasing southwards. [12] showed that major local magmatic activities were concentrated along ENE and WSW zones. The age pattern suggests that the parent magma were locally derived from several simultaneous high level magma chambers connected to a common deeper source. The emplacement of these ring complexes was controlled by fracture systems in the basement.

The main phase of acid magmatism in Nigerian Younger Granite province commenced during Triassic times and continued to migrate in a generally southerly direction until the close of the Jurassic [13]. The cessation of magmatism might have been synchronous with the initiation of the South Atlantic.

[13] proposed three stages of development of the Nigerian ring complexes:

1 Early stage of a large rhyolite volcano which prior to the end of its stage, large amount of magma accumulated in the synvolcanic reservoir about $5 \mathrm{~km}$ beneath the surface.

2 Caldera and ring dyke stage when the centre of the volcanic structure within a ring fault collapsed, magma arose along the fault and crystallized as granite porphyry which was extruded into the caldera rocks

3 Intrusive stages were the warming phase of igneous activity when smaller granite intrusions were emplaced at increasing depth levels. The magma evolved and crystallized at lower temperatures and as lower assemblages. They rocks are composed of biotite granite.

The Younger Granites have a clear topographical definition and there is usually a close coincidence between the geological and topographical boundaries at the margins of the granites. They form continuous ranges and plateaus, which rise between 91 and $305 \mathrm{~m}$ above the surrounding level plains [7]. The Younger Granites are underlain by Older Granites, migmatites and meta-sediments of the basement complex.

\section{Material and Methods}

Data sets for this study are a topographic map and an airborne magnetic map of the Kagoro Younger Granite complex and its environments. Magnetic data were compiled from four analogue aeromagnetic sheets. A submap for the study area was produced from the four magnetic sheets in an [14] environment. Regional correction was based on the International Geomagnetic Reference Field (IGRF) epoch of January 1, 1974. Contours of the total magnetic intensity were in gamma $(\gamma)$ but treated in nanoTesla $(\mathrm{nT})$ in this study. The magnetic intensity values vary between 32,600 and 33,160 nT.

Digitization of the aeromagnetic contoured maps was performed with [14] software so as to view and manipulate them in a computer as arrays of pixel, with each pixel corresponding to a digital number that represents the intensity level of the pixel in the range. In ILWIS, contours are interpolated by first calculating the shortest distances to the two closest contour lines and then calculating the output value weighted according to the distance [15]. The result from the interpolation is a digital representation in raster format of a continuous surface [16] where every raster cell is assigned an attribute value corresponding to the interpolated variable.

\section{Coordinate System Projection}

The Universal Transverse Mercator (UTM) projection was used to place prominent features on all maps in this research. This coordinate system is the basis for many standardized regional maps. Clarke 1880 given in [14] ellipsoid is applied to the central meridian scale factor of 0.9996 to measure distances on the maps. Coordinate system projection parameters for this study are presented in Table 1.

Table 1 Coordinate System Projection Parameters

\begin{tabular}{|l|l|l|l|l|l|l|l|}
\hline Projection & $\begin{array}{l}\text { Datum } \\
\text { Area }\end{array}$ & Datum & \multicolumn{2}{l|}{$\begin{array}{l}\text { Ellipsoid } \\
\text { Parameters }\end{array}$} & Ellipsoid & Hemisphere & Zone \\
\hline \multirow{2}{*}{ UTM } & Nigeria & Minna & $\mathrm{a}$ & 6378249 & $\begin{array}{l}\text { Clarke, } \\
1880\end{array}$ & Northern & 32 \\
\cline { 4 - 8 } & & & $1 / \mathrm{f}$ & 293.465 & & \\
\hline
\end{tabular}

(After, [4])

\section{Description of the Magnetic Field}

Segment map of the total magnetic intensity shown in Fig. 2 is characterized by positive magnetic intensity values between 7500 and 8150 nanoTesla (nT), which to every contour level a value of $25,000 \mathrm{nT}$ is to be added. The lowest magnetic contour values closure is centred over the Kagoro granite rocks at the central 
part. This closure is structurally aligned along NE - SW direction. Lower magnetic values are also observed at the northeast around Pari, Daw and Jal etc community areas. Some lower values occur around Ashafa and Ungwa $\mathrm{Pa}$ areas in the northwest. Ungwa Atile area also hosts magnetic low contour values. Paralleling these contours to the south and to the north are higher contour values trending along NE - SW direction. These values occupy a greater proportion of the area.

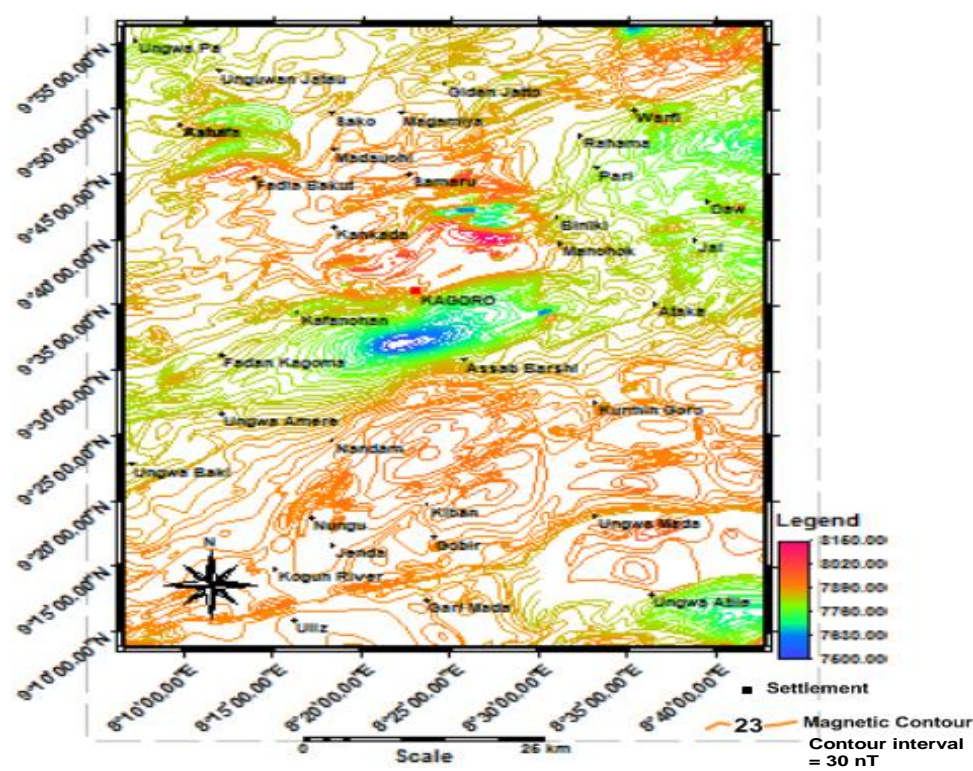

Fig. 2 Magnetic Intensity Map

\section{Regional Field}

Regional anomaly field values of the magnetic map in Fig. 3 vary between 7789.1 and $7896.6 \mathrm{mGal}$. The field has no particular direction, however, higher regional values sandwiched lower ones at the northeast and northwest. From the north to the south the same magnetic regional highs that separate the northeast to southwest lows serve as regional lows. Some regional lows also separate higher values at the southern part along E - W direction.

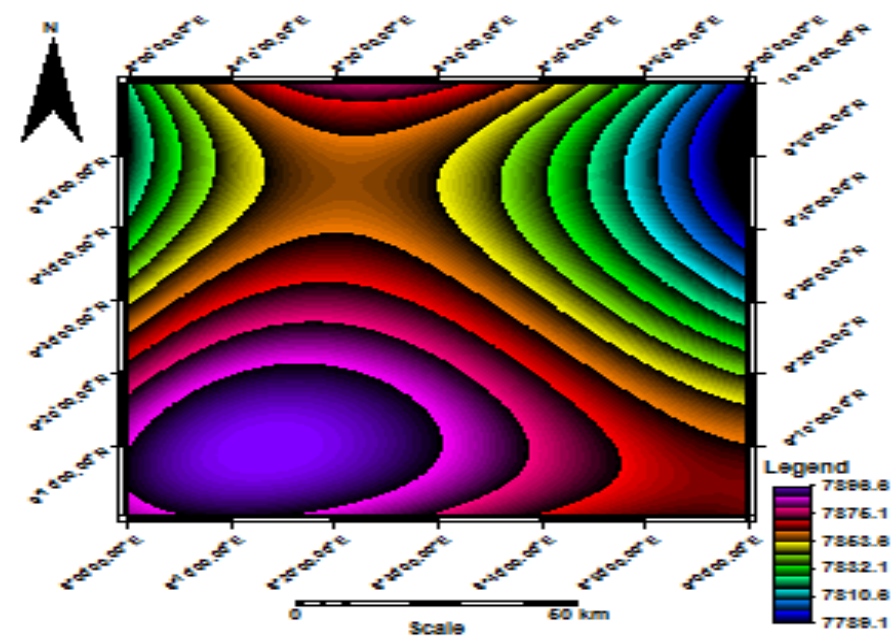

Fig 3 Regional Anomaly

\section{Residual Field}

Fig. 4 shows the magnetic residual anomaly map obtained after subtracting the regional field from the intensity field. The residual contour values range from -180 to $+160 \mathrm{nT}$. The main closure of the residual map is located at the central part of the area. The closure has the shape of a slipper, oriented along NNE - SSW direction. Communities of Fadan Kagoma, Kafanchan, Kagoro and Ataka areas are at the periphery of this closure. Two separate closures sandwiched by this closure are located at the south of Kagoro and the southeast of Ungwa Baki. 
A single closure is situated east of Namdam area and towards the extreme northwestern part of the map is a NE - SW directional closure. The closure at the northeastern part is located north of Warfi area. At the central region are two sandwiched closures whose saddle is oriented along $\mathrm{E}-\mathrm{W}$ direction.

An oblong shaped closure occurs in the northwest and trends along NE - SW direction. Trending along the same NE - SW direction is another closure at the edge of the northwestern part. A sizeable partial closure is observed around the eastern borders of Warfi, Rahama and Pari areas. Also a partial closure occurs around Ungwa Mada area.

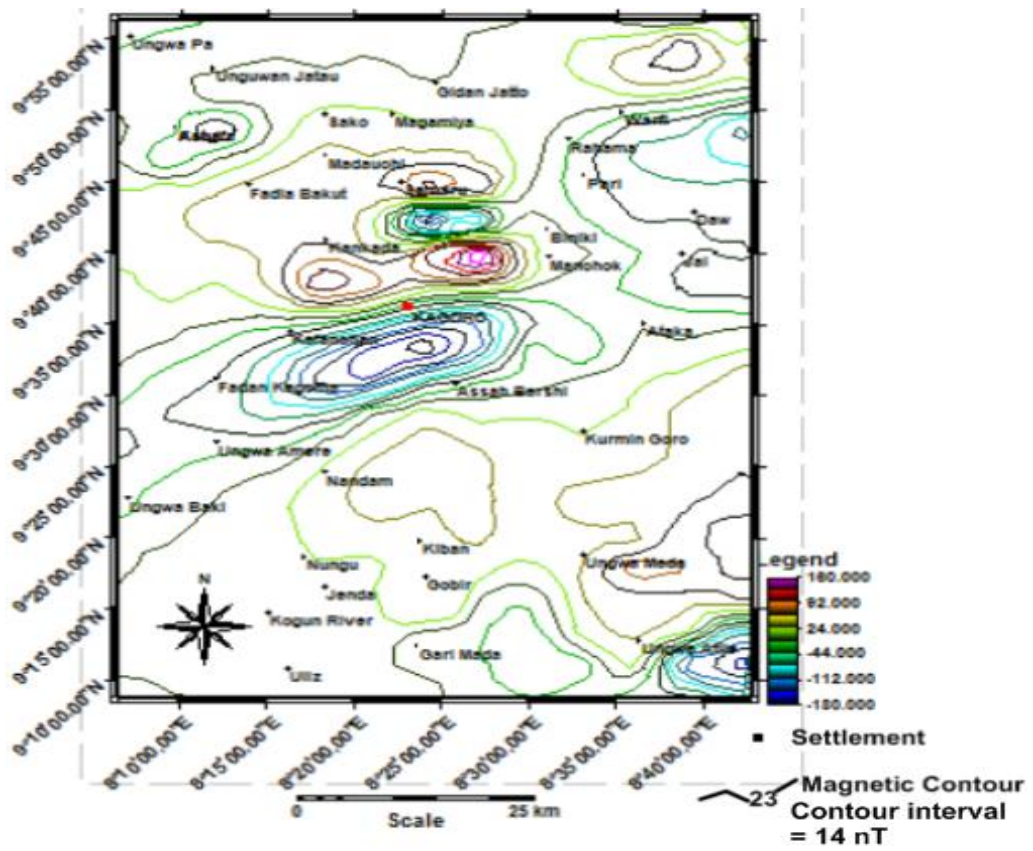

Fig 4 Residual Anomaly

\section{Quantitative Interpretation of Magnetic Profiles}

Quantitative interpretation is to obtain information about the depth to the magnetic source, its shape and size, and details about its magnetization either by direct method, where the field data are interpreted to yield a physical model or by inverse method, where models are generated from which theoretical anomalies are generated and fitted statistically against the observed data.

The regional fields along five horizontal profiles $(\mathrm{MH})$ and along four vertical profiles (MV) were obtained by third degree polynomial fitting using [17] software. The residual results were obtained by subtracting the regional background from the intensity. Fig.5 shows the five horizontal $(\mathrm{MH})$ and four vertical (MV) profiles superimposed on the residual map.

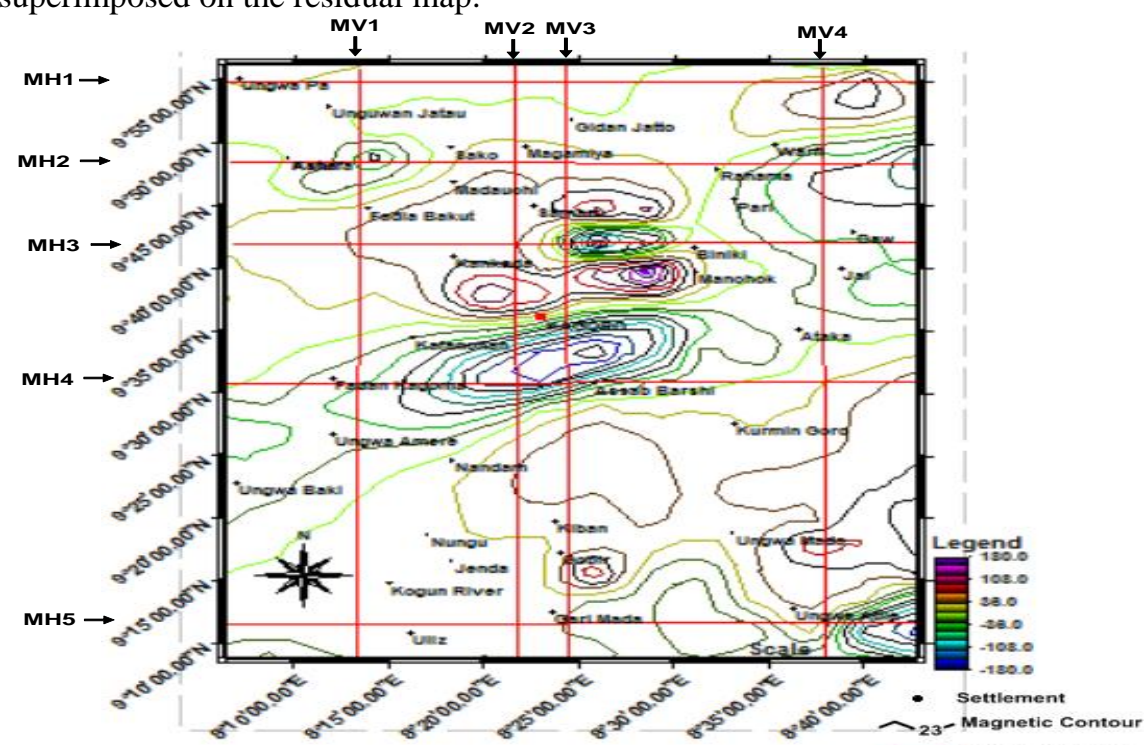

Fig. 5 Profiles Superimposed on Residual Map 
The residual anomalies were accounted for by the application of Geomodel software which consists of "Mag2dc"algorithms. Geomodel is [18] two and one half dimensional (2.5D) computer software. Susceptibility values for the different rock units were taken from typical values in literature. The upper part of every model shows the observed and calculated data. The lower part shows the rock units after adjustment of their depths.

\section{The Profiles}

MH1 has seven rock bodies; six of them are plutonic rocks and one is a volcanic body (Fig. 6). The susceptibility values of the plutonic rocks lie between -0.0048 and -0.0014 SI units. The width varies between 0.94 and $8.70 \mathrm{~km}$. The thickness is within 7.6 and $14.1 \mathrm{~km}$. The susceptibility value of the volcanic unit is $0.0031 \mathrm{SI}$ units. Its width is $3.73 \mathrm{~km}$ and the thickness is estimated at $9.2 \mathrm{~km}$.

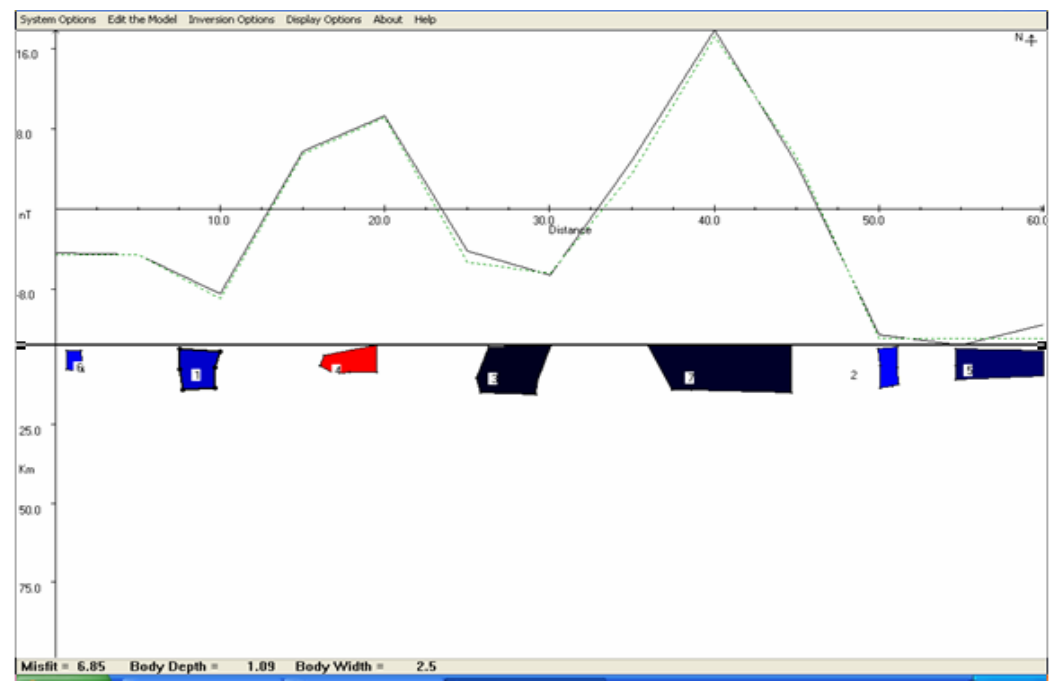

Fig. 6 Model along Profile MH1

MH2 has three plutonic and four volcanic bodies (Fig. 7). The susceptibility values accepted for the models of the plutonic rocks lie between -0.0075 and -0.0058 SI units. The lateral dimension is between 1.10 and $9.73 \mathrm{~km}$ and the vertical extension is between 4.9 and $14.4 \mathrm{~km}$. The susceptibility values for the volcanic rocks range between 0.0056 and 0.0145 SI units. The individual bodies have lateral spreads between 0.48 and $10.28 \mathrm{~km}$, while their thicknesses vary from 8.2 and $13.4 \mathrm{~km}$

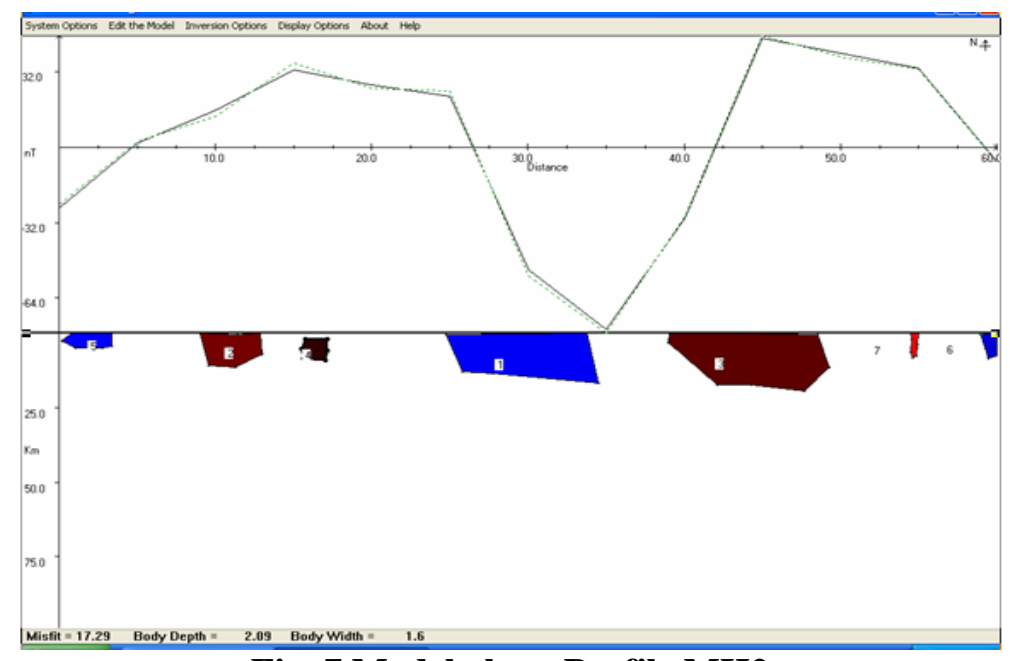

Fig. 7 Model along Profile MH2

Along MH3 profile section shown in Fig. 8, there are three plutonic and three volcanic rock bodies. The range of susceptibility values of the plutonic rocks are between -0.0090 and -0.0023 SI units. The calculated widths are between 0.68 and $8.98 \mathrm{~km}$. The thicknesses are between 7.1 and $14.8 \mathrm{~km}$. The volcanic rock bodies 
possess susceptibility values between 0.0047 and 0.0075 SI units. The widths are between 1.78 and $15.11 \mathrm{~km}$, while interval of 12.5 and $13.0 \mathrm{~km}$ contains the calculated thickness.

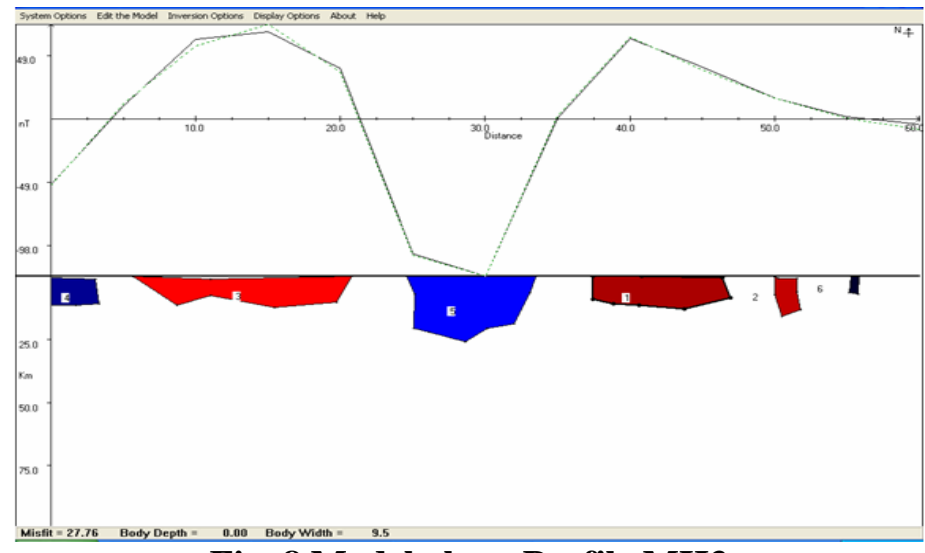

Fig. 8 Model along Profile MH3

Three plutonic and four volcanic rock bodies characterized MH4 section in Fig. 9. The plutonic bodies have susceptibility values within the range of -0.0094 and -0.0026 SI units, width between 0.62 and $8.66 \mathrm{~km}$. Its thickness measures between 5.4 and $8.2 \mathrm{~km}$. Susceptibility values between 0.0045 and 0.0091 SI units were used for the volcanic models. The individual bodies have lateral spread of between 0.66 and $19.92 \mathrm{~km}$ and vertical thickness between 5.4 and $7.6 \mathrm{~km}$.

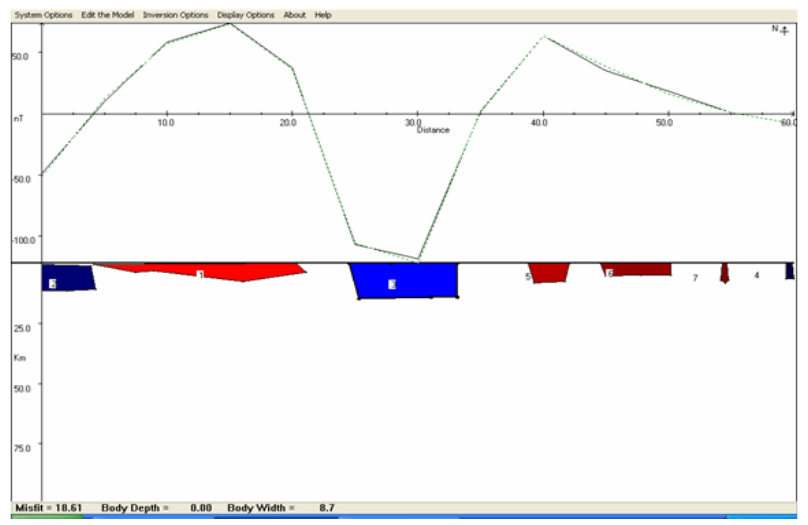

Fig. 9 Model along Profile MH4

Profile section MH5 given in Fig. 10 contains four plutonic and four volcanic rocks units. Minimum susceptibility value for the plutonic bodies is -0.0028 SI units and the maximum value is $-0.0016 \mathrm{SI}$ units. The bodies are between 1.58 and $5.35 \mathrm{~km}$ wide and between 8.2 and $12.5 \mathrm{~km}$ thick. Volcanic rock bodies have susceptibility values between 0.0020 and 0.0025 SI units, spreading within 0.87 and $3.44 \mathrm{~km}$ distance. The estimated values for the thicknesses are 7.1 to $13.0 \mathrm{~km}$.

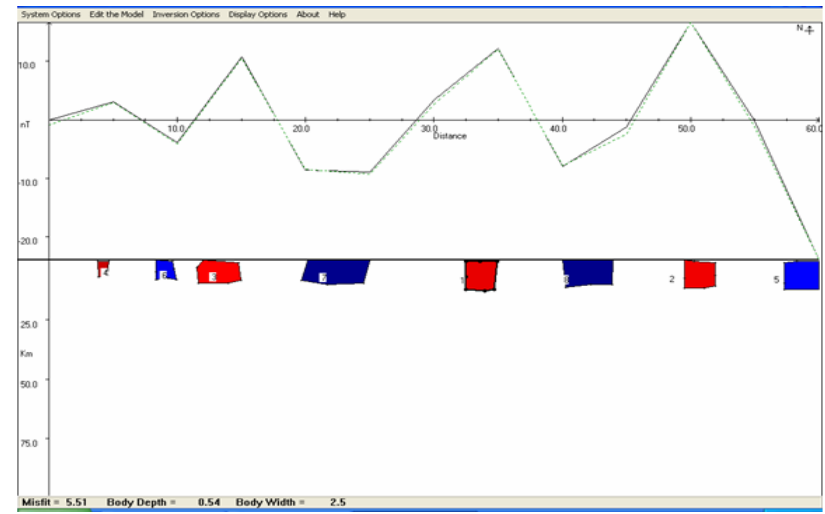

Fig. 10 Model along Profile MH5 
Fig. 11 shows that MV1 profile has eight anomalous bodies consisting of three plutonic and five volcanic types. The susceptibility values of the plutonic type vary from -0.0022 and -0.0196 SI units. Width range of between 4.54 and $15.22 \mathrm{~km}$ was determined. The range of the thickness is between 8.7 and $11.2 \mathrm{~km}$. The lowest susceptibility value obtained from the volcanic bodies is 0.0011 SI units, while the highest value is 0.0055 SI units. The widths of the volcanic rocks vary between 2.44 and $21.87 \mathrm{~km}$ and their thicknesses are between 7.1 and $12.9 \mathrm{~km}$.

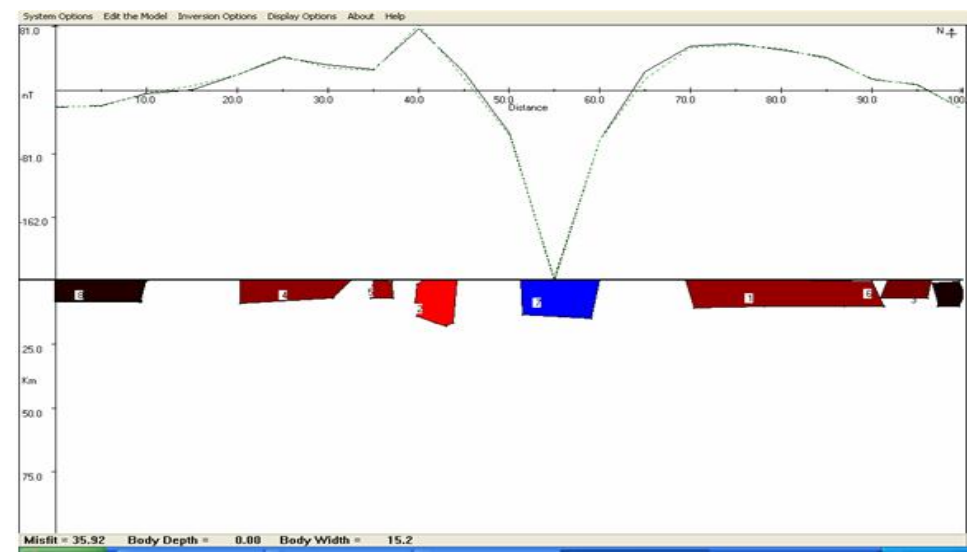

Fig. 11 Model along Profile MV1

Out of the seven modeled bodies along MV2 given in Fig. 12, three are of plutonic origin and four are volcanic. The range of susceptibility values for the plutonic bodies varies between -0.0025 and -0.0024 SI units; the width is calculated at between 1.36 and $9.42 \mathrm{~km}$ and the thicknesses lie within range of 4.1 and $9.5 \mathrm{~km}$. For the volcanic bodies, the susceptibility values are between 0.0013 and 0.0056 SI units, the widths range from 6.42 to $23.92 \mathrm{~km}$ and the thicknesses measure 4.7 to $10.4 \mathrm{~km}$.

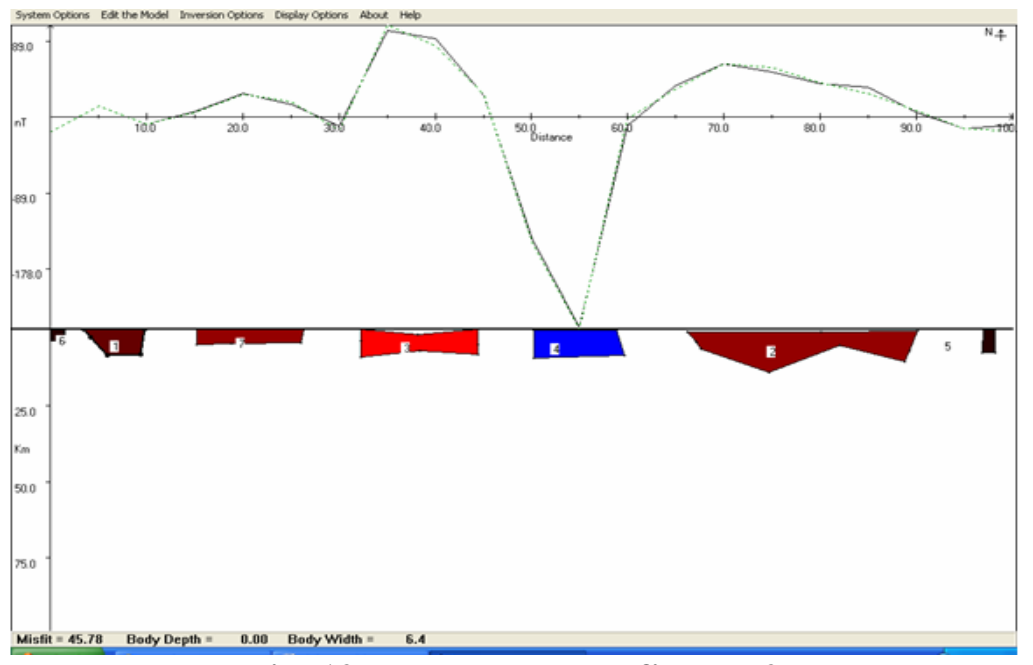

Fig. 12 Model along Profile MV2

Cross section along MV3 is made up of eight individual rock bodies; three of which are plutonic and five are volcanic (Fig. 13). Susceptibility values for the plutonic lie between -0.0088 and -0.0018 SI units. The width falls within 2.02 and $11.6 \mathrm{~km}$ and estimated thicknesses are between 8.2 and $10.4 \mathrm{~km}$.. Volcanic bodies along the same path have susceptibility values between 0.0025 and 0.0174 SI units. This resulted in the width range of between 2.98 and $25.89 \mathrm{~km}$ and estimated thicknesses between 6.0 and $10.7 \mathrm{~km}$. 


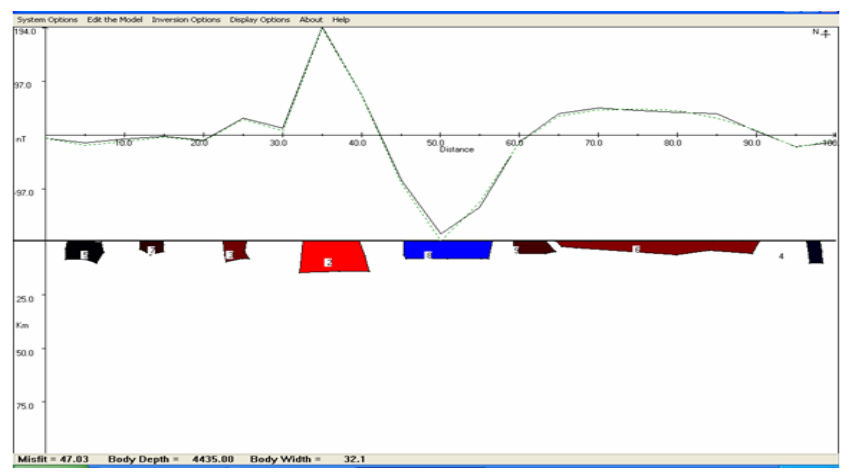

Fig. 13 Model along Profile MV3

Models of MV4 profile shown in Fig. 14 produced eight separate bodies consisting of four plutonic and four volcanic. Susceptibility minimum and maximum for the plutonic bodies are -0.0063 and -0.0018 SI units respectively. The lateral dimensions are between 4.73 and $8.35 \mathrm{~km}$ and the thicknesses vary from 7.6 to $13.2 \mathrm{~km}$. The volcanic rock bodies possess susceptibility values of 0.0022 to 0.0040 SI units. The calculated widths are between 0.21 and $11.78 \mathrm{~km}$ while their thicknesses vary within 6.0 and $11.2 \mathrm{~km}$.

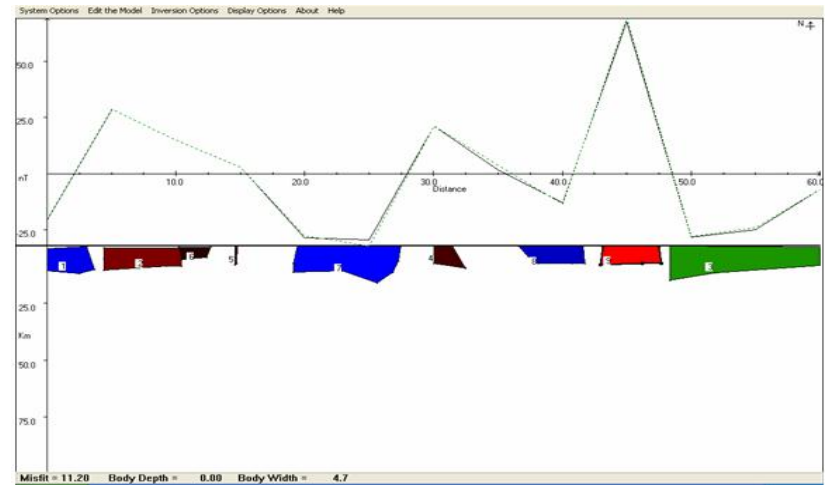

Fig. 14 Model along Profile MV4

Table 1 gives a summary of key parameters of the different rock models. Six plutonic rock units (MH2, MH3, MH4, MV1, MV2 and MV3) possess minimum number of three bodies each and only MH1 attained the maximum number of six bodies. A minimum lateral extension of $0.62 \mathrm{~km}$ and maximum of $15.22 \mathrm{~km}$ were obtained from MH4 and MV1 respectively. Minimum thickness of $4.1 \mathrm{~km}$ was calculated for MV2, while MV1 produced maximum thickness of $15.2 \mathrm{~km}$.

The volcanic rock unit MH1 contains only one body. MV1 and MV3 have 5 bodies each. Lateral spread of 0.21 $\mathrm{km}$ obtained from MV4 is the minimum width while $25.89 \mathrm{~km}$ revealed by MV3 is the maximum. Estimated minimum thickness of $4.7 \mathrm{~km}$ was obtained from MV2. Calculated thickness of $13 \mathrm{~km}$ observed from MH5 is the maximum.

Table 1 Summary of Key Parameters of the Models

\begin{tabular}{|l|c|c|l|l|}
\hline Rock Name & Profile Name & Number of Bodies & Width Range (km) & \multicolumn{1}{|c|}{ Thickness Range (km) } \\
\hline & MH1 & 6 & $0.94-8.70$ & $7.6-14.1$ \\
& MH2 & 3 & $1.10-9.73$ & $4.9-14.4$ \\
& MH3 & 3 & $0.68-6.98$ & $7.1-14.8$ \\
& MH4 & 3 & $0.62-8.66$ & $5.4-11.7$ \\
& MH5 & 4 & $1.58-5.35$ & $8.2-12.5$ \\
& MV1 & 3 & $4.54-15.22$ & $8.7-15.2$ \\
& MV2 & 3 & $1.36-9.42$ & $4.1-9.5$ \\
& MV3 & 3 & $2.02-11.60$ & $8.2-10.4$ \\
& MV4 & 4 & $4.73-8.35$ & $7.6-13.2$ \\
\hline \multirow{5}{*}{ Volcanic } & MH1 & 1 & 3.73 & 9.2 \\
& MH2 & 4 & $0.48-10.28$ & $12.5-14.4$ \\
& MH3 & 3 & $1.78-15.11$ & $5.4-8.2$ \\
& MH4 & 4 & $0.66-19.92$ & $7.1-13.0$ \\
& MH5 & 4 & $0.87-3.44$ & $7.1-12.9$ \\
& MV1 & 5 & $2.44-21.87$ & $4.7-10.4$ \\
& MV2 & 4 & $6.42-23.92$ & $6.0-10.7$ \\
& MV3 & 5 & $21.98-25.89$ & $6.0-11.2$ \\
\hline
\end{tabular}


Variation in susceptibility values of the models are the results of differences in mineral and chemical compositions of the rocks [19]. The maximum thicknesses of $15.2 \mathrm{~km}$ for the Kagoro Granite complex given by the results compare favourably with $18.75 \mathrm{~km}$ over the Jos - Bukuru intrusion determined [20].

\section{Conclusion}

Magnetic field intensity of Kagoro and environs is characterized by positive values between 32,500 and 33,150 nT. Intensity closures are oriented along NE - SW direction. The regional field has no particular trend direction. Residual anomaly contour values are negative and positive ranging from -180 to $+160 \mathrm{nT}$. Main closure of the regional anomaly is observed at the central part and is oriented along NNE - SSW direction. Residual anomaly closures align along E - W, NE - SW and NNE - SSW directions. Directional patterns of the magnetic maps are in conformity with those of the Nigeria basement and Younger granite rocks. Their separation suggest that the rock bodies occur as different individual units and at different levels.

Models of the plutonic bodies estimated maximum vertical extensions of 14.1, 15.2, 9.5 and $10.4 \mathrm{~km}$ along MH1, MV1, MV2, and MV3 respectively. These profiles traversed the Kagoro complex. Hence the depth of Kagoro Younger granite complex extends between 9.5 and $15.2 \mathrm{~km}$. The volcanic rocks and their associates along the same profiles attained thicknesses between 4.7 and $13.0 \mathrm{~km}$. These depths are associated to a major fault which cuts across the area.

\section{References}

[1] A. Onugba and O. M. Eduvie, Hydrogeology of Nigeria: UNICEF workshop on Groundwater, Jos, 2003,20 p.

[2] J. B. Wright, Fracture system in Nigeria and initiation of fracture zones in the South Atlantic. Tectonophysics, $34,1976,43-47$.

[3] P. O. Oluyide, Structural Trends in the Nigerian basement complex. Precambrian Geology of Nigeria. Geological Survey of Nigeria Publication, 1988, $93-98$.

[4] A. N. Udoh, An interpretation of satellite imageries of Nigeria $7^{\circ} 40^{\prime}$ N. Precambrian Geology of Nigeria. Geological Survey of Nigeria Publication, 1988, $99-102$.

[5] P. I. Olasehinde and M. O. Awojobi, Geological and geophysical evidences of a North - South fracture system east and west of the upper Gurara river in Central Nigeria. Water Resources Journal, Nigerian Association of Hydrogeologist, 15, 2004,33 -37.

[6] Microsoft Encarta. http//Encarta.msn.com, encwish@ microsoft.com, 2007

[7] W. N. MacLeod, D. C. Turner and E. P. Wright, The geology of the Jos Plateau, 1: General geology. Geological Survey of Nigeria. Bull., 32, 1965, $118 \mathrm{p}$.

[8] M. O. Oyawoye, The geology of the Nigerian basement complex. Journal of Nigeria Mining. Geology and Metallurgical Society, $1(2), 1964,87-103$

[9] M. O. Oyawoye, The basement complex of Nigeria, in T. F. J. Dessauwagie and A. J. Whiteman (Eds). Africa Geology, University of Ibadan, 1972, $67-99$

[10] R. R. E. Jacobson, W. N. MacLeod and R. Black, Ring complexes in the younger granite province of Northern Nigeria. Geological Society of London, Mem. 1, 1958, 72 p.

[11] D. C. Turner, Structure and petrology of the younger granite ring complexes, in C. A. Kogbe, (Ed), Geology of Nigeria, Rock View International,( France, 1989) $175-190$.

[12] M. A. Rahaman, O. Van Breeman, J. N. Benner and P. Bowden, Age migration of anarogenic ring complexes in Northern Nigeria. Journal Geological, 92, 1984, $173-184$.

[13] P. Bowden, O. van Breemen, J., Hutchinson and D. C. Turner, Palaeozoic and mesozoic age trends for some ring complexes in Niger and Nigeria. Nature, 259, 1971, $297-299$.

[14] ILWIS 3.3 Academic, 2005, ITC, RSG/GSD.

[15] B. Gorte, and W. Koolhoren, Interpretation between isolines based on Borgefors distance transform. ITC Journal 3,1990, $245-247$.

[16] E. M. Scheteselaar, P. M. van Dijk and Y. A. Al Fasatwi, Digital image processing of geophysical data using raster-based GIS. ITC Journal 3, 1990, $248-252$

[17] OriginLab7, Scientific graphing and analysis software. OriginLab.com., 2002

[18] G. R. J. Cooper, Geomodel for windows. School of Geosciences, University of the Witwatersrand Johannesburg, South Africa. www.wits.ac.za/science/geophysics/gc.htm, 2003.

[19] W. M. Telford, Z. P. Geldart, R. E. Sheriff and D. A. Keys, Applied geophysics (Cambridge University Press, 1976).

[20] S. C. Alkali and S. N. Yusuf, Gravity study over Jos - Bukuru younger granite complex, North Central Nigeria. Scholars Research Library, Archives of Physics Research, 1(4), 2010, 178 - 191. 